\title{
THE CORRELATION BETWEEN STUDENTS' READING COMPREHENSION TOWARD STUDENTS' ENGLISH ACADEMIC ACHIEVEMENT
}

\author{
Elly Susanti ${ }^{1}$, Dionesia Irmadila ${ }^{2}$ \\ ${ }^{1}$ IKIP-PGRI Pontianak, ${ }^{2}$ SMA 1 Ketungau \\ ${ }^{1}$ labilabi34@gmail.com, 2dionesiaselaluirma@gmail.com
}

\begin{abstract}
This research was aimed to investigate the significance of correlation between students' reading comprehension toward students' English academic achievement. The population was the second grade students. By using cluster random sampling, XI IPA 1 and XI IPS 2 were being the sample. The total number of population was 195 students and the total number of sample was 66 students. Written test framed by the aspects of reading comprehension was applying to figure out the students' reading comprehension score. Documentation technique of students' English report book was applying to figure out the students' English academic achievement score. The result shows that there is a significant correlation between students' reading comprehension and students' English academic achievement. It is implied the students' who got higher in reading comprehension test tend to get outstanding score also in their English academic achievement. In addition, it can be one of the concern contribution to increase students' English academic achievement through implementation of reading comprehension's aspects. The teacher needs to implement the aspects of reading comprehension as the focus learning material and synergize it with the other main aspects of English academic achievement.
\end{abstract}

Keywords: Correlation, Reading Comprehension, English Academic Achievement.

\begin{abstract}
ABSTRAK
Penelitian ini bertujuan untuk menyelidiki signifikansi korelasi antara pemahaman membaca siswa terhadap prestasi akademik bahasa Inggris siswa. Populasinya adalah siswa kelas dua. Dengan menggunakan cluster random sampling, XI IPA 1 dan XI IPS 2 menjadi sampel. Jumlah total populasi adalah 195 siswa dan jumlah total sampel adalah 66 siswa. Tes tertulis yang dirujuk dari aspek pemahaman membaca yang diterapkan untuk mengetahui skor pemahaman membaca siswa. Teknik dokumentasi, buku rapor bahasa Inggris siswa diaplikasikan untuk mencari skor prestasi akademik bahasa Inggris siswa. Hasilnya menunjukkan bahwa ada korelasi yang signifikan antara pemahaman membaca siswa dan prestasi akademik bahasa Inggris siswa. Hal ini mengimplikasikan bahwa siswa yang mendapat lebih tinggi dalam tes pemahaman membaca cenderung mendapatkan nilai yang luar biasa juga dalam prestasi akademik bahasa Inggris para siswa. Guru perlu menerapkan aspek pemahaman bacaan sebagai bahan fokus pembelajaran dan mensinergikannya dengan aspek-aspek utama lainnya dari prestasi akademik bahasa Inggris siswa.
\end{abstract}

Kata Kunci: Korelasi, Pemahaman Membaca, Prestasi Akademik Bahasa Inggris 


\section{INTRODUCTION}

Reading is the most crucial skills in learning a foreign language besides listening, speaking and writing, and it is also used as a bridge to understand the scientific books written in English. Reading is also not easy to be comprehended knowing the meaning of words alone does not help the reader to comprehend and understand what the text is all about. Based on the researcher's observation at SMA Negeri 1 Ketungau Tengah while conducting teaching practice in 2017, the researcher found some facts which were some students that the researcher tough at the first semester of second grade students in IPA 1 and IPS 3 showed that the students who had good at reading comprehension perform better to students' English academic achievement. In another hand, there were some students who did not apprehend enough at reading comprehension tend to get lower grade of their English academic achievement.

From the observation above the researcher decided to do the interview which the students who tend to have a better English academic achievement were interested with the story, they were comprehending enough with material, vocabulary in the text and knowing the context of text about. While the students who tend to get lower grade of their English academic achievement explained to the researcher that they lack of vocabulary in the text, the text was too long and complicated to be comprehended, the story was so bored, they did not even know about the story in Indonesian language, they did not like to answer the main idea because it would make them read the story all over again and they were run out the time and they could not find the inference because too many of the players in the text.

Based on the above observations and interviews the researcher was interested in administrating the research regarding reading comprehension and students' English academic achievement because the researcher would like to investigate the relationship between students' reading comprehension toward students' English academic achievement to the second grade students in SMA Negeri 1 Ketungau Tengah in the academic year 2017/2018. 


\section{Research Problem}

Based on the background of the title selection above, the formulation of the research problems in this research were formulated in the following questions below:

1. Is there any significant correlation between students' reading comprehension toward students' English academic achievement to the second grade students of SMAN 1 Ketungau Tengah in the academic year of 2017/2018?

2. What is the significance level of the correlation between students' reading comprehension toward students' English academic achievement to the second grade students of SMAN 1 Ketungau Tengah in the academic year of $2017 / 2018 ?$

\section{Research Purposes}

The main purposes of this research were to answer the formulation of the problems mentioned above, the research purposes of this research were as followed below:

1. To find out if there is any significant correlation between students' reading comprehension toward students' English academic achievement to the second grade students of SMAN 1 Ketungau Tengah in the academic year of $2017 / 2018$.

2. To know the significance level of the correlation between students' reading comprehension toward English academic achievement to the second grade students of SMAN 1 Ketungau Tengah in the academic year of 2017/2018.

\section{Research Terminology}

This research was providing the terminology that aimed to avoid the ambiguity of the terms in this research, they were as stated on following descriptions below:

\section{Reading Comprehension}

Reading comprehension is an active process of exploring and getting the information of the text and knowing the capability to construct the meaning of written text in process of applying some aspects of reading comprehension while reading it, King and Stanley cited in (Putra, 2012) stated that they are five aspects 
of reading comprehension, they are; finding the main idea, finding the factual information, finding the meaning of vocabulary context, identifying inference, and identifying reference. In this research fifth aspects of reading comprehension will be used for being the framework test of the first variable which in students' reading comprehension.

\section{English Academic Achievement}

In our society academic achievement is considered as a key criterion to judge one's total potentialities and capacities. Hence, English academic achievement occupies a very important place in education as well as in the learning process. As stated by (Borase, 2015, p. 1), academic achievement represents performance outcomes that indicate the extent to which a person has accomplished specific goals that were the focus on activities in instructional environments, specifically in school, college, and university. The most common indicator of achievement generally refers to a student's performance in academic areas such as reading, language arts, math, science and history as measured by achievement tests (Cunningham, 2012).

English academic achievement represents performance or specific outcomes indicating the extent to which a person has accomplished specific goals or indicators in Kurikulum Tingkat Satuan Pendidikan (KTSP) 2006 in learning syllabus that was utilized by SMAN 1 Ketungau Tengah which were speaking, reading, writing and listening.

\section{METHODOLOGY}

\section{Research Design}

The researcher administrated a quantitative as the research study in correlational research. According to (Fraenkel, Wallen, \& Hyun, 2012, p. 331) the correlational study is for knowing the correlation between variables or more without any attempt to influence them. It means there is no subjectivity of manipulating the research variables. There are two type of correlational research which are commonly used in educational research, they are; the explanatory design or known as relationship study and the prediction design. In this research, the researcher will administrate the explanatory design or known as relationship study 
(Creswell, 2008, p. 339). The explanatory is purpose to clarify the understanding of important phenomena by identifying or investigating the relationship of variables (Fraenkel, Wallen , \& Hyun, 2012, p. 332).

\section{Technique of Data Collection Instrument}

The research instrument were simply devices to obtain the information which has relevance to the study or research project and it has many choices to be used. In this research, the researcher attempted the measurement technique and documentation technique for collecting the data.

\section{Students' Reading Comprehension Test}

For collecting the data of students' reading comprehension the researcher used measurement technique, the researcher had been developing the test based on the aspects reading comprehension which are finding main idea finding the factual information, finding the meaning vocabulary context identify inference, identify reference. The researcher also used the narrative text and recount text because it were emphasized by Kurikulum Tingkat Satuan Pendidikan (KTSP) 2006 in learning syllabus which utilized by SMA Negeri 1 Ketungau Tengah. The test consists of 25 items of tryout items and it had separated to the sample of second grade students in SMAN 1 Ketungau Tengah and the valid and reliable one had been being used for measuring the students' reading comprehension.

\section{Students' English Academic Achievement}

For collecting the data of students' English academic achievement the researcher was attempted documentation technique, the researcher had been using documentation and it was taken from students' English academic achievement score in students' English report book which were already including listening, speaking, reading, and writing based on Kurikulum Tingkat Satuan Pendidikan (KTSP) 2006 in learning syllabus for the first semester of second grade students in senior high school which utilized by SMA Negeri 1 Ketungau Tengah. 


\section{RESEARCH FINDINGS}

\section{The Significant of Correlation}

To know the correlation between two both variables; students' reading comprehension and students' English academic achievement, the researcher was using Pearson product moment correlation and ran the data by using Statistical Package for the Social Sciences (SPPSS) 16. The result showed that there was the value of Pearson correlation 0,730 , it means there was a positive significant strong correlation between students' reading comprehension and students' English academic achievement to the second grade students of SMA Negeri 1 Ketungau Tengah in the Academic Year 2017/2018.

Table 1. Correlations

\begin{tabular}{llll}
\hline \multirow{2}{*}{$\mathrm{RC}$} & Pearson Correlation & $\mathrm{RC}$ & $\mathrm{EAC}$ \\
\cline { 2 - 4 } & Sig. (1-tailed) & 1 & $\mathbf{. 7 3 0}^{\text {** }}$ \\
\cline { 2 - 4 } & $\mathrm{N}$ & 66 & .000 \\
\hline \multirow{2}{*}{ EAC } & Pearson Correlation & $\mathbf{7 3 0}^{\text {*** }}$ & 66 \\
\cline { 2 - 4 } & Sig. (1-tailed) & .000 & 1 \\
\cline { 2 - 4 } & $\mathrm{N}$ & 66 & 66 \\
\hline
\end{tabular}

**. Correlation is significant at the 0.01 level (1-tailed).

\section{The Significance Level of Correlation}

The significance level of correlation between students' reading comprehension and students' English academic achievement was classified by using the table of the classification of correlation levels (Ludico, Spauldin, \& Voegtle, 2006, p. 233). In this research, significance level of correlation was include in positive strong relationship, it can be concluded that there is a positive strong significant correlation between students' reading comprehension and students' English academic achievement to the second grade students of SMA Negeri 1 Ketungau Tengah in the Academic Year 2017/2018.

Table 2. The Classification of Correlation Levels

\begin{tabular}{|c|c|}
\hline Size of Correlation & Strength of Correlation \\
\hline $0-0.19$ & No Relationship or Weak Relationship \\
\hline $0.20-0.37$ & Slight Relationship \\
\hline $0.35-0.64$ & Moderately Strong Relationship \\
\hline $0.65-0.84$ & Strong Relationship \\
\hline $0.84-$ Greter & Very Strong Relationship \\
\hline
\end{tabular}

Taken From (Ludico, Spauldin, \& Voegtle, 2006, p. 233) 


\section{CONCLUSION}

This research had been answering the research problem number one and two which were in first previous page, that there is a significant correlation between students' reading comprehension toward students' English academic achievement that to the second grade students of SMA Negeri 1 Ketungau Tengah in the academic year 2017/2018 and the students' who get higher score of reading comprehension tend to get outstanding score of the English academic achievement as well.

Thus, it can be concluded that the reading comprehension is one of the important factor and it is also desirable that this can be applied as a focus of learning in terms of improving students' English academic achievement score. Therefore, it is highly suggested and expected to be the point concern by education on this issue which can be implemented at school or at the English language education study program as well as this can be the implication for the teacher and lecturer as well.

\section{RESOURCES}

Anggraini, S. (2017). The Correlation between Reading Comprehension and Academic Achievement of English Education Study Program Students of UIN Raden Fattah Palembang. Tarbiyah dan Keguruan Faculty of Islamic State University Raden Fatah, English Education Study Program, Palembang.

Borase, C. (2015). Co-relation Study of Classroom Environment and Academic Achievement of. India.

Creswell, J. W. (2008). Educational Research (4th ed.). (M. Buchholtz, \& K. Mason, Eds.)

Cunningham, J. (2012). Student Achievement. Denver, Colorado: National Conference of State Legislatures.

Fraenkel, J. R., Wallen, N. E., \& Hyun, H. H. ( 2012). How to design and evaluate research in education (Vol. 8th). (S. Kiefer, Ed.) New York: The McGrawHill Companies, Inc. 
Ludico, M. G., Spauldin, D. T., \& Voegtle, K. H. (2006). Methods in educational research : from theory to practice (1st ed.). Market Street, San Francisco: John Wiley \& Sons, Inc. All rights reserved.

Menaka, B., \& Jebaraj , J. (2017). Reading Comprehension in Relation to Academic Achievement in English among Higher Secondary Students (Vol. 5). Sulur, India. Retrieved from https://doi.org/10.5281/zenodo.810468.

Ponkshe, S. (2013). English Reading Comprehension as a Predictor for Academic Successes in First Year B. SC. Nursing Course in India. 2(4).

Purwantoro, H., Asrori, M., \& Wahyuni, D. S. (2015, October to November). Correlation between Vocabulary Masery, Reading Comprehension and Students' Engliah Achievement. (EnglishEducation Department, Teacher Training andEducation Faculty Sebelas Maret).

Putra, A. (2012). A Study on Students' Ability in Comprehending Spoof Text at The Second Grade Student of SMA PGRI. Pekanbaru: Unpublised. https://www.scribd.com/doc/103009737/Jurnal-Spoof-Texts 